\title{
STRUCTURAL STRENGTH OF CEMENTED CARBIDES
}

\author{
SOROKA Olena ${ }^{1}$, RODICHEV Iuriy ${ }^{1}$, VORONTSOV Borys ${ }^{2}$, PROTASOV Roman ${ }^{3 *}$ \\ ${ }^{I}$ G. S. Pisarenko Institute for Problems of Strength, Timiryazevs'ka 2, 01014, Kyiv, Ukraine \\ ${ }^{2}$ National Technical University of Ukraine "Igor Sikorsky Kyiv Polytechnic Institute", 03056, Kyiv, Ukraine \\ ${ }^{3}$ Faculty of Mechanical Engineering, Slovak University of Technology in Bratislava, Institute of transport \\ technology and designing, Nám. Slobody 17,812 31 Bratislava, Slovakia, e-mail: roman.protasov@stuba.sk
}

\begin{abstract}
The concept "structural strength of tool materials" got further development. The refusals of cemented carbide cutting plates, when heavy machining were analyzed. It was shown that $70 \ldots 80 \%$ of refusals are the microchipping of cutting edges, tool cutting part chipping, cutting plate macrofracture. To assess cutting plate total carrying capacity and the influence of different methods of cemented carbides modification, bending tests were held. Local fracture resistance and damageability of cutting edge were assessed under its continuous scanning.
\end{abstract}

KEYWORDS: structural strength, cemented carbides, cutting plate, chip, microchipping, bending strength, macrofracture, continuous scanning, modification

\section{Introduction}

The refusals of cutting plates are due to wear or fracture [1-5]. The mechanism of refusal depends on machining regime and machine. It is well known, that heavy machining, especially under roughing, leads to the large zone and value of tensile service stresses. In our previous paper, we substantiated the difference in approaches to solve the problem of cutting plate performance assurance when the limit state of cutting plate is wear or fracture. We also discussed the concept 'structural strength of tool materials' and outlined the methods of its assessment [5].

One of these methods is bending tests. In accordance with standards documents ISO 3327:2009 (Hardmetals - Determination of transverse rupture strength), ASTM B406 - 96 (Standard Test Method for Transverse Rupture Strength of Cemented Carbides) and JIS 0261983 (TRS of cemented carbides - CCTMAS, Japan) for cemented carbide prismatic and cylindrical ground test-pieces are tested under three-point or four-point bending. According to ISO limit strength can be also measured using a notched bend test-piece. It reduces the scatter and the strength values obtained are higher (because failures from large defects are excluded). It is emphasized: "The ISO standard geometries are all acceptable for use but it is important to recognize that different geometries can give different strength values, by a factor of up to $50 \%$. Test-piece surface preparation can have an even bigger effect than geometry through the manufacture the test-pieces. The increase can be as much as $100 \%$ " [6]. To assess the impact of structural and technological factors special samples that differ from the standard one are used [7].

Due to large differences in manufacturing technology of standard test-pieces and cutting plates, test results of standard test-pieces in bending tests do not reflect the cutting cemented carbide plate's actual properties, which are caused by technological and structural factors. Test results of standard test-pieces only identify important trends in mechanical behavior of a material that can be the basis for orienting assessment of tool performance. Therefore, testing of cutting plates under three-point bending or cantilever bending to get the value of bending structural strength of cemented carbide is more reasonable. 
Chipping resistance as well as bending strength of cutting plate is an important component of structural strength. It is necessary to assess cutting edge damage. We proposed the method of cutting edge continuous scanning to assess characteristics of fracture resistance and damageability of cutting plates edges [5].

The goal is analysis of refusals under heavy machining, further development of the concept 'structural strength of tool materials', assessment of cemented carbides structural strength characteristics, comparison of these characteristics in original state with characteristics of modified ones.

\section{Analysis of the failed plates}

Particularly extreme in terms of load on the cutting plates is roughing, which occurs with significant depths of cutting (15... 20mm) and feeds (up to $3 \mathrm{~mm}$ ), and is accompanied by fluctuations in the physical and mechanical properties of the processed material.

Fig. 1 shows a series of photographs of uncoated milling plates R390-180G12M-PM and Sandwich MKTC SNGX 250800 with PVD coatings after their failure as the result of machining on heavy machines.

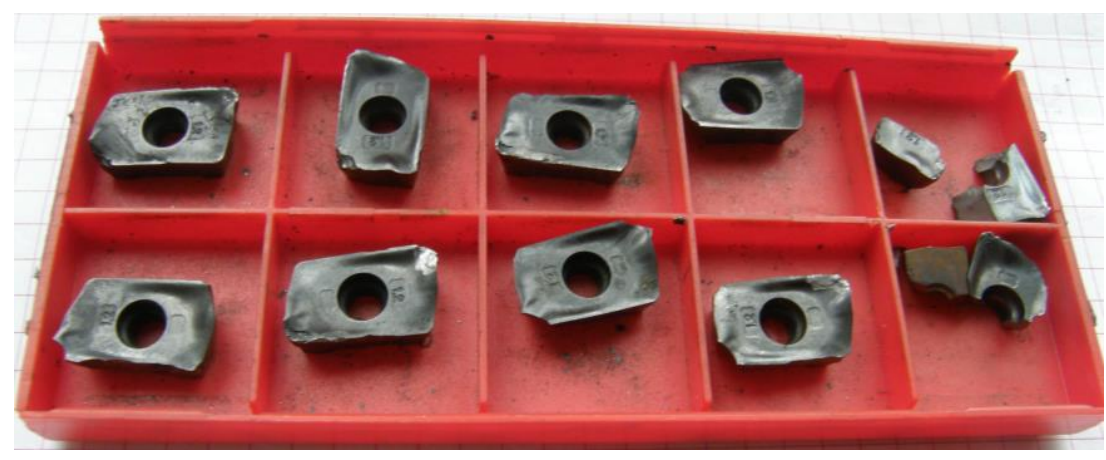

a)

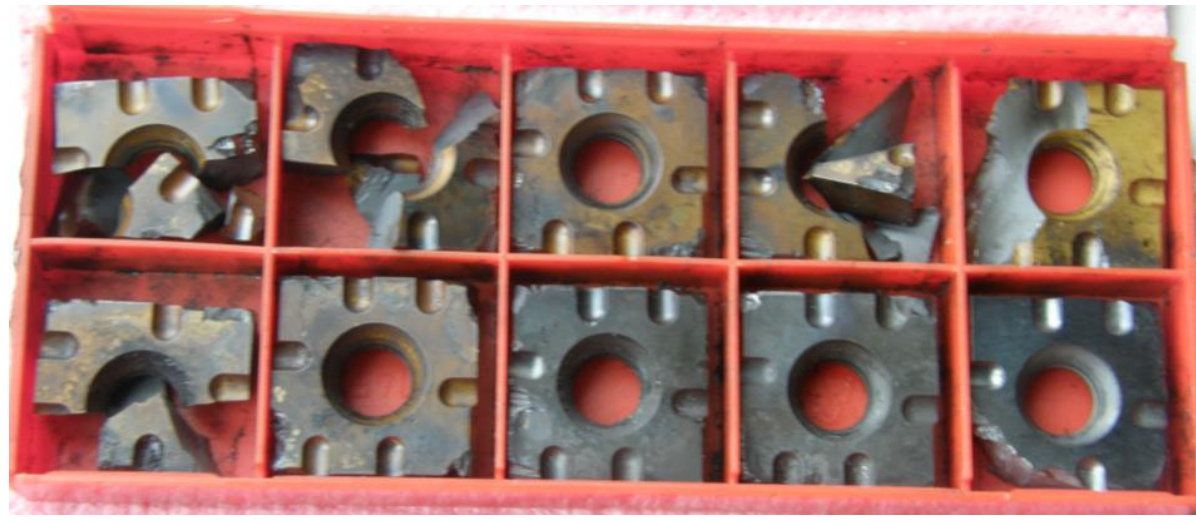

b)

Fig. 1 Milling plates R390-180G12M-PM and MKTC SNGX 250800 after failure after processing on heavy machines

The nature of damage and failure of cemented carbide plates is considered. The example is shown in Fig. 2. 

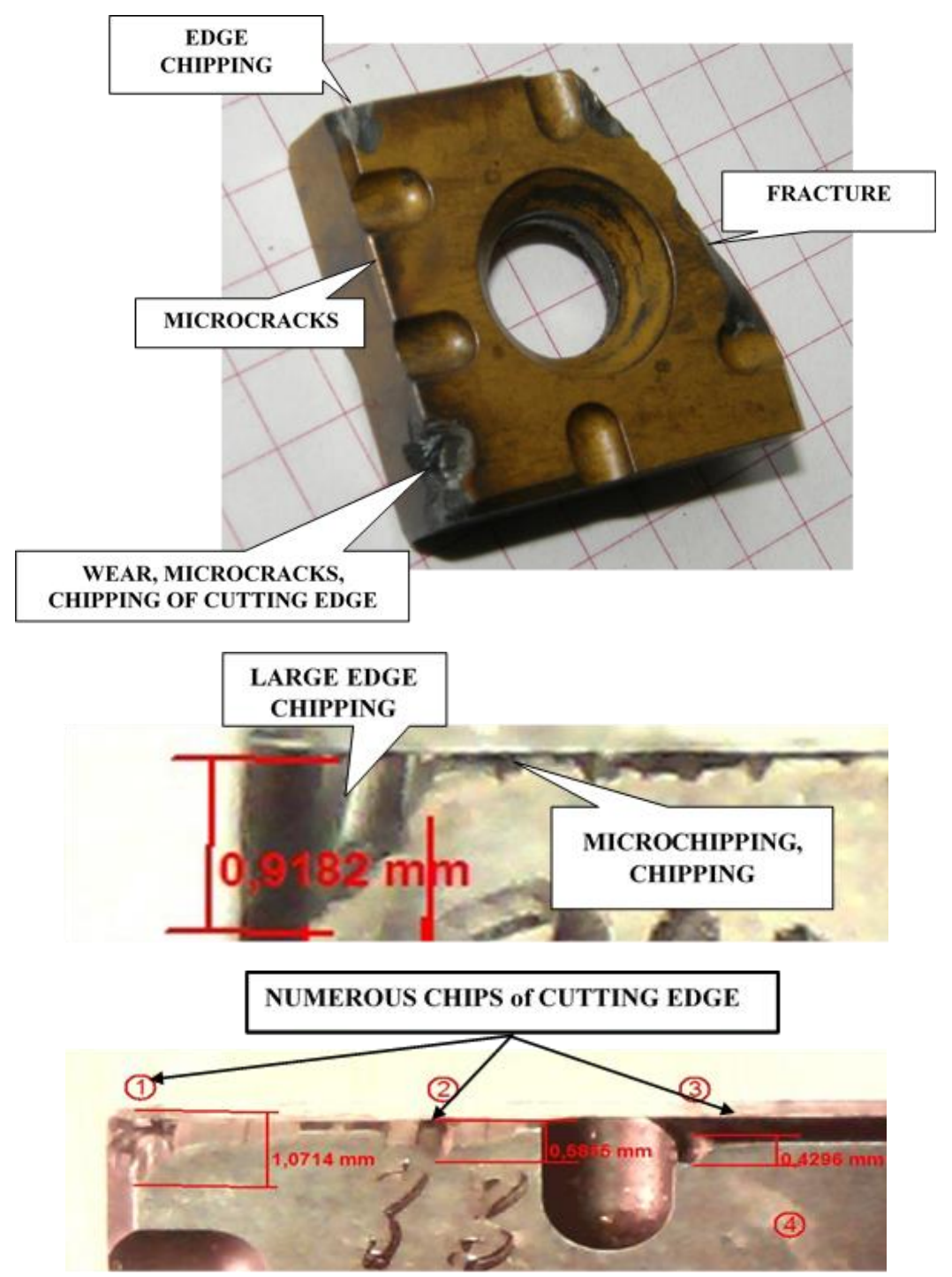

Fig. 2 The nature of damage and failure for milling plate MKTC SNGX 250800 after processing on heavy machines

Analysis of the failed plates showed that the main stages of their damage and fracture are:

-fracture and abrasion of the wear-resistant coating;

- cutting edge blunting;

- formation of microcracks;

- cutting edge microchipping by the mechanisms of brittle and quasi-brittle fracture with elements of the development of tear and shear cracks;

- localized macrochipping in corner zones and in areas of increased microcracking;

- cutting plate macrofracture.

\section{Experimental}

Bending strength tests. For three-point bending tests of cemented carbide cutting plates special loading devices, which allow hydraulic machine ZD - 4 and ZD - 40 testing, were developed $[4,5]$. The example of the device for hydraulic machine $\mathrm{ZD}-40$ is shown in Fig.3. 


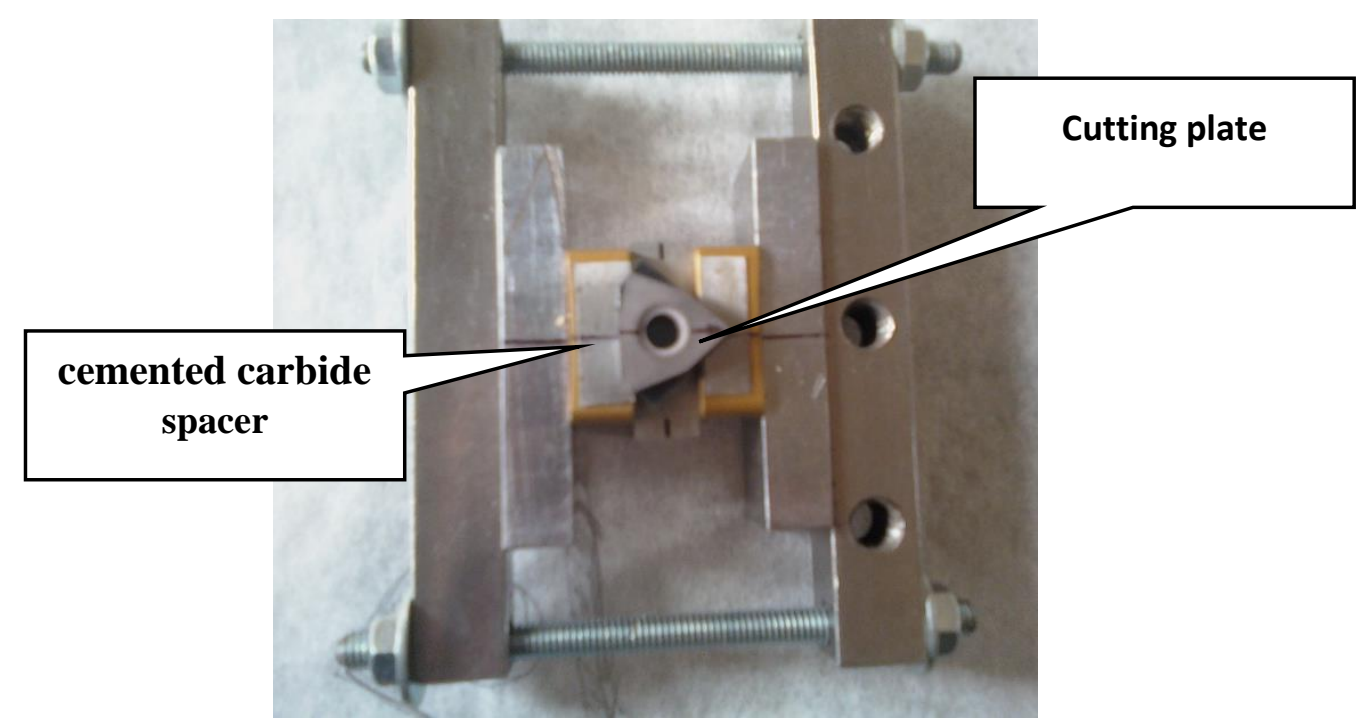

Fig. 3 The device for three-point bending tests of cemented carbide cutting plates

We also assessed the breaking load value $P_{\max }$ under cantilever bending in accordance with procedure [8, 9] (Fig.4).

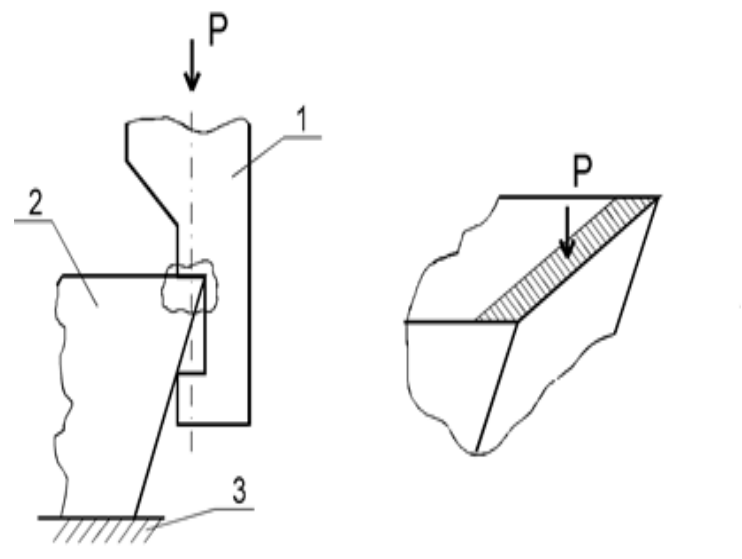

Fig. 4 A sketch of cantilevered bending of cutting plates:

1 - loading element; 2 - cutting plate; 3 -support [9]

Three-point bending tests as well as cantilever bending we used as a comparative strength criterion for cutting plates in original and modified state [5, 9].

Edge effects tests. The method to assess the damageability and local fracture resistance of cutting plate edge is scanning of front or back surfaces. For this purpose the special loading device was used (Fig 4) [5, 10]. The load element was cemented carbide cutting plate and the load values were controlled by etalons with different weight.

The parameters of damageability characterize the geometry of scanned cutting edge. They are depth of chips $B_{c}$, its maximum $B_{c}{ }^{\text {max }}$ and mean $B_{c}{ }^{\text {mean }}$ values and their ratio, length of single chip $l_{c}$, total length of chipped areas $L_{c}$, density $L_{c} l l$ ( $l$ - the length of the scanning) and the total area $F_{c}$ of chips. The local fracture resistance of edge is characterized by the ratio of load to the mean depth of chips $P / B_{c}{ }^{\text {mean }}$.

\section{$4 \quad$ Results and Discussion}

Structural bending strength. We investigated three types of cemented carbide cutting plates (titanium-tungsten -cobalt and tungsten-cobalt) under three point bending tests $[2,3]$. For all types of plates, the rake face of the cutting plate was placed in the area of tensile stresses. 
Cutting plates ((WC - 79\%, TiC - $15 \%$, Co-6\%) were also tested when the flank face of the plate was under tensile stresses. It makes possible to take into account the influence of technological and structural factors on the bending strength. It's shown that when the rake face was in tensile zone, the source of failure is next to the hole of cutting plate. The bending tests when tensile stresses are on the flank face showed that the average value of the bending strength is 2.5 times higher than for plates tested when tension is on the rake face. The obtained results were compared with the bending strength of cemented carbide test-pieces according to considering range of variation in published data from various data sources [9]. The results are presented in the Table1. It's obtained that the mean values of strength limit for cutting plates (structural strength) $\sigma_{b}{ }^{S}$ are much less than the values of strength limit for standard test-pieces $\sigma_{b}$ and differ by a factor of up to $50 \% \ldots . .78 \%$ when the rake face of the plate was under tensile stresses. When the flank face is under tension, $\sigma_{b}{ }^{S}$ tends to the value for standard test-pieces or even exceeds it.
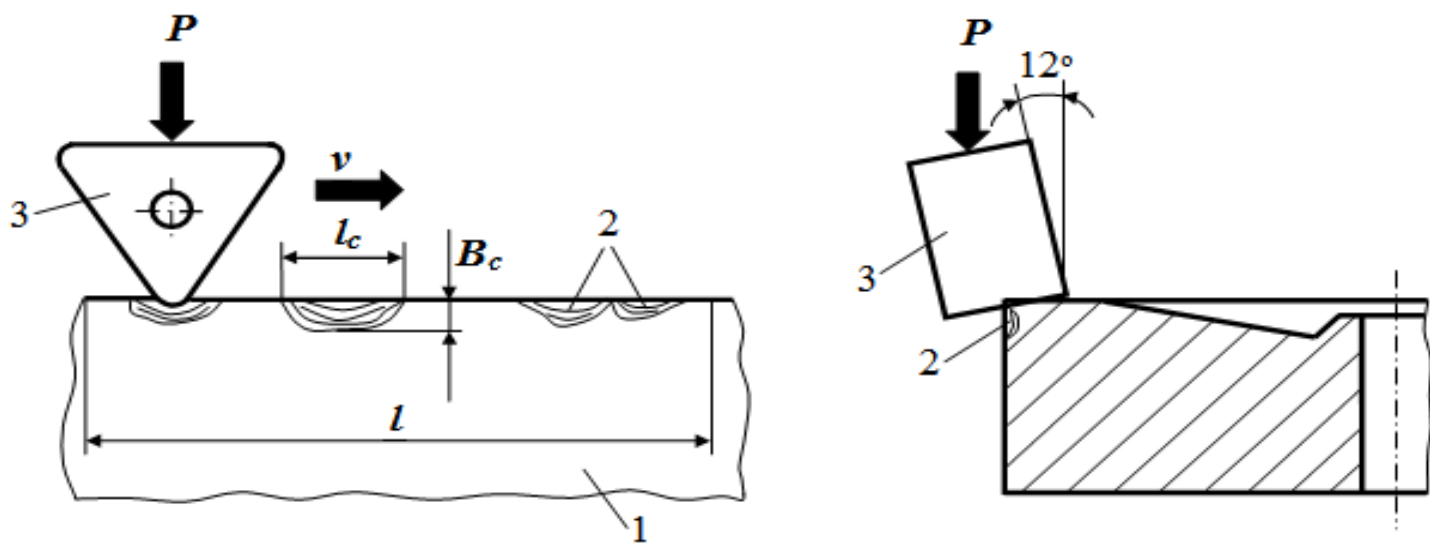

Fig. 5 The scheme of cutting plate edge loading by cemented carbide indenter: 1 - investigated cutting plate; 2 - chipped edges; 3 - loading punch

For all tests scatter of structural bending strength limit $\sigma_{b}{ }^{S}$ is observed. Fig. 6 presents the statistical Weibull distribution for the bending strength of titanium-tungsten-cobalt plates, when the flank face is in the tensile zone.

The results of the assessment of bending structural strength for modified plates are in two lower rows of the Table 1. The method of modification is pulsed magnetic field treatment (PMFT), which is the bulk strengthening method. It is attractive since the process is carried out at room temperature and magnetic fields are easy to produce and control. The physical basis of PMFT concerning to the high-speed steel tool are formulated in [12]. According to [13] the method of pulsed magnetic treatment increases the wear-resistance and lifetime of high-speed steel tool at $30 \ldots 50 \%$. There are some limited data about the effect of PMFT on hardness and wear-resistance of cemented carbide [14]. It was found that the treatment of carbide tool with PMF leads to an increase in bending strength limit up to $16 \%$ for tungsten-titanium-cobalt and up to $30 \%$ for tungsten-cobalt plates (Tab.1). The value of structural strength limit after PMFT tends to the value of strength limit for standard test-pieces.

The another comparative results for 20 cutting plates $(85 \% \mathrm{WoC}, 5 \% \mathrm{TiC}, 10 \% \mathrm{Co})$ in original state (ten plates) and modified with ion nitriding in hydrogen free medium (ten plates) were obtained under cantilevered bending tests with breaking load $P_{\max }$ registration by strain gauge dynamometer [9]. The method of ion nitriding in hydrogen free media is an effective process of surface hardening. It is thoroughly studied and widespread in industrial applications for modification of metallic materials [15]. It has been established that ion nitriding in hydrogen free saturating media is a promising technique for enhancing the cemented carbide cutting 
plates wear resistance [16]. We demonstrated that for modified plates the average value of breaking load $P_{\max }\left(P_{\max }=2080 \mathrm{~N}\right)$ increases by $15 \%$ at cantilevered bending of modified inserts as compared to the inserts in original state $\left(P_{\max }=1810 \mathrm{~N}\right)$, while the spread of values decreases (dispersion $D^{2}\left(P_{\max }\right)$ is 540 for plates in original state and 445 - in modified).

Table 1 Comparative characteristics of structural strength of cemented carbides in original and modified state (cutting plates) and bending strength for standard cemented carbide test-pieces according to [11]

\begin{tabular}{|c|c|c|c|c|c|}
\hline \multirow[t]{2}{*}{ Plate } & \multirow{2}{*}{$\begin{array}{l}\text { The } \\
\text { face } \\
\text { under } \\
\text { tensile } \\
\text { stresses }\end{array}$} & \multicolumn{2}{|c|}{$\begin{array}{l}\text { Structural bending } \\
\text { strength limit } \sigma_{b} S\end{array}$} & \multirow[t]{2}{*}{$\bar{\sigma}_{b}^{S} / \sigma_{b}$} & \multirow{2}{*}{$\begin{array}{c}\text { Degree } \\
\text { of } \bar{\sigma}_{b}^{S} \\
\text { increase } \\
\text { (strengt } \\
\text { hening, } \\
\% \text { ) }\end{array}$} \\
\hline & & $\begin{array}{c}\text { mean } \\
\text { value } \bar{\sigma}_{b} S, \\
\mathrm{MPa}\end{array}$ & $\begin{array}{c}\text { minimum value/ } \\
\text { maximum value } \\
\sigma_{b}{ }_{\text {min }} / \sigma_{b}{ }_{S}{ }_{\max }\end{array}$ & & \\
\hline$(85 \% \mathrm{WoC}, 5 \% \mathrm{TiC}, 10 \% \mathrm{Co})$ Original state & rake & 892 & $711 / 1046$ & $0.5 \ldots 0.75$ & - \\
\hline (79\%WoC, $15 \% \mathrm{TiC}, 6 \% \mathrm{Co})$ Original state & rake & 642 & $547 / 804$ & $0.58 \ldots 0.78$ & \\
\hline (79\%WoC, $15 \% \mathrm{TiC}, 6 \% \mathrm{Co})$ Original state & flank & 1600 & $1460 / 1719$ & $0.8 \ldots 1.08$ & \\
\hline$(92 \% \mathrm{WoC}, 8 \% \mathrm{Co})$ Original state & rake & 1027 & $976 / 1078$ & $0.51 \ldots 0.69$ & \\
\hline$(92 \%$ WoC, $8 \% \mathrm{Co})$ Original state & flank & 1470 & $1400 / 1780$ & $0.74 \ldots 0.99$ & \\
\hline (85\%WoC, $5 \% \mathrm{TiC}, 10 \% \mathrm{Co})$ After PMFT & rake & 1037 & $762 / 1280$ & $0.6 \ldots 0.9$ & 16 \\
\hline (79\%WoC, $15 \% \mathrm{TiC}, 6 \% \mathrm{Co})$ After PMFT & rake & 735 & $608 / 804$ & $0.67 \ldots 0.8$ & 14 \\
\hline (92\% WoC, $8 \%$ Co) After PMFT & rake & 1480 & $1230 / 1650$ & $0.74 \ldots 1$ & 30 \\
\hline
\end{tabular}

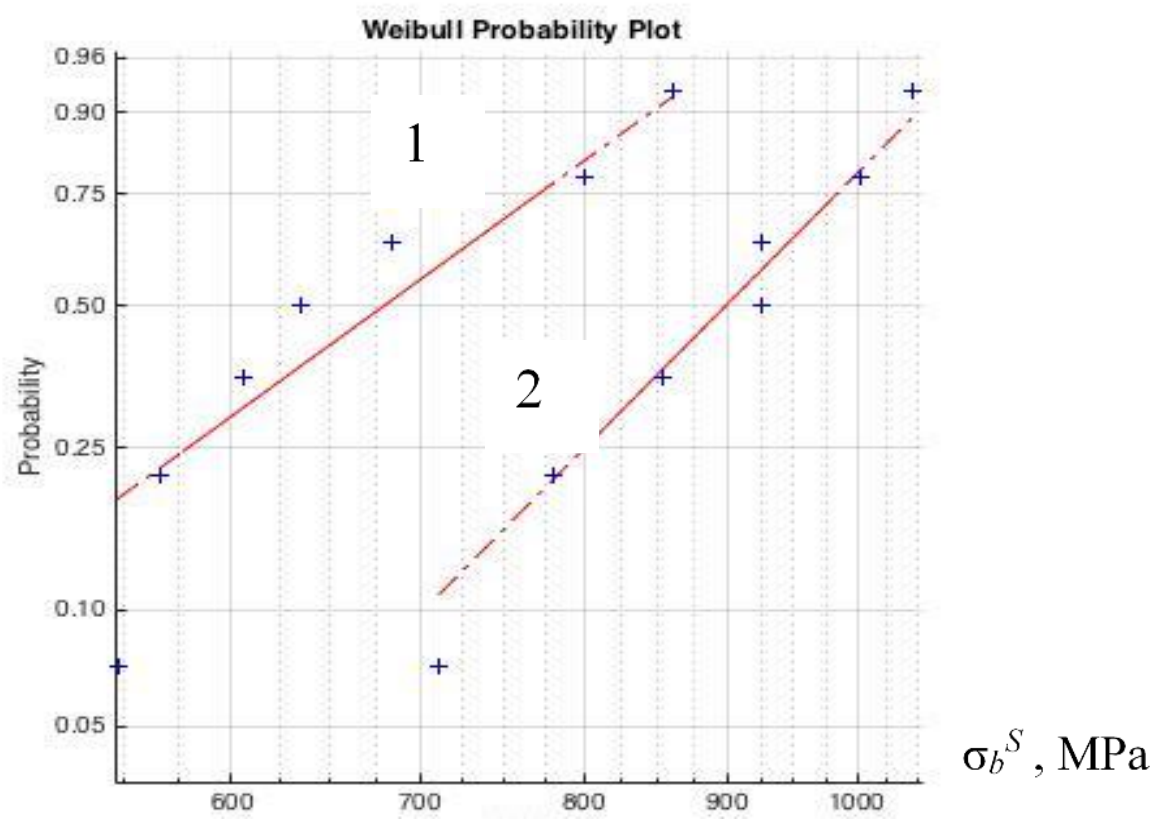

Fig. 6 Weibull distribution for the structural bending strength, when the flank face is in the tensile zone: 1 - $(85 \% \mathrm{WoC}, 5 \% \mathrm{TiC}, 10 \% \mathrm{Co}) ; 2$ - $(79 \% \mathrm{WoC}, 15 \% \mathrm{TiC}, 6 \% \mathrm{Co})$ 
Damageability and fracture resistance of the edge of cemented carbide cutting plate. Under the continuous scanning, we investigated characteristics of the edge damageability and the local fracture resistance of cemented carbide cutting plate PNMM 120408 (WC 92\%, Co $8 \%$ ) in its original state and modified with $5 \mu \mathrm{m}$-thickness wear-resistant PVD columnar coating TiAlN [10]. The results are presented in Table 2.

Table 2 Characteristics of the edge damageability and fracture resistance of cutting plate PNMM 120408

\begin{tabular}{|l|c|c|c|c|c|c|}
\hline \multirow{2}{*}{} & \multicolumn{2}{|c|}{$P=35,9 \mathrm{~N}$} & \multicolumn{2}{c|}{$P=50,6 \mathrm{~N}$} & \multicolumn{2}{c|}{$P=80 \mathrm{~N}$} \\
\cline { 2 - 7 } & $\begin{array}{c}\text { Original } \\
\text { state }\end{array}$ & $\begin{array}{c}\text { TiAlN } \\
5 \mu \mathrm{m}\end{array}$ & $\begin{array}{c}\text { Original } \\
\text { state }\end{array}$ & $\begin{array}{c}\text { TiAlN } \\
5 \mu \mathrm{m}\end{array}$ & Original state & $\begin{array}{c}\text { TiAlN } \\
5 \mu \mathrm{m}\end{array}$ \\
\hline$B_{c}{ }^{\text {max }}, \mathrm{mm}$ & 0,088 & 0,143 & 0,132 & 0,154 & 0,23 & 0,154 \\
\hline$B_{c}{ }^{\text {mean }}, \mathrm{mm}$ & 0,057 & 0,087 & 0,0736 & 0,084 & 0,11 & 0,095 \\
\hline$P / B_{c}{ }^{\text {mean }}$ & 614 & 402 & 679 & 595 & 729 & 842 \\
\hline$L_{c}, \mathrm{~mm}$ & 1,32 & 8,08 & 5,425 & 8,15 & 9,64 & 9,91 \\
\hline$L_{c} l, \%$ & 14,7 & 89,7 & 47,7 & 78,3 & 86 & 100 \\
\hline$F_{c}, \mathrm{~mm}^{2}$ & 0,062 & 0,681 & 0,248 & 0,577 & 0,800 & 0,828 \\
\hline
\end{tabular}

Under the local loading up to some loading value $(60 \mathrm{~N})$ the application of brittle columnar wear-resistant coating results in implementation of mechanisms of brittle fracture and so increase of mean sizes of chips, density and total area of chips as well as reduction of cutting edge fracture resistance. These results raise a question of the PVD columnar coatings appropriateness for cutting plates, which operation conditions leads to cutting edge chipping. In addition, it's important to emphasize that PVD columnar coating didn't affect bending strength.

\section{CONCLUSION}

Analysis of the failed plates under roughing with heavy machining identified the main stages of their damage and fracture: fracture and abrasion of the wear-resistant coating; cutting edge blunting; microcracking; cutting edge microchipping; localized macrochipping in corner zones and in areas of increased microcracking; cutting plate macrofracture.

The further development of the concept 'structural strength of cemented carbides' is presented. The significant scatter of structural bending strength is observed. It's established that structural bending strength is much less than the bending strength for standard samples when the rake face of the plate was under tensile stresses and tends to the bending strength of samples, when the flank face is under tension.

The influence of pulsed magnetic field (PMFT), ion nitriding and columnar PVD coatings on the characteristics of structural strength is determined.

\section{REFERENCES}

[1] Stupnytskyy, V., She Xianning, S. "Comparative analysis of simulation results of hardto-cut materials machining by coated cutting tools", Strojnícky časopis - Journal of Mechanical Engineering 70 (2), pp. 153 - 166, 2020. DOI: 10.2478/scjme-2020-0028

[2] Vorontsov, B., Bosansky, M., Kyrychenko, I., Kuzmenko, N., Stupnytskyy, V., Kuleshkov, Y., Ustinenko, A. "Methods of Designing Gear's Machining Tools with the 
Hyperboloid Cutting Part", Strojnícky časopis - Journal of Mechanical Engineering 70 (1), pp. 135 - 142, 2020. DOI: 10.2478/scjme-2020-0013

[3] Lipa, Z., Peterka, J., Pokorny, P., Václav, Š, Buransky, I. "On methods of theoretical investigation of cutting forces in metal machining", Strojnícky časopis - Journal of Mechanical Engineering 61 (3) pp. 183 - 191, 2010.

[4] Soroka, O., Rodichev, Y., Kovalov, V., Vasilchenko, Y. "Strengthening of carbide cutting tool for heavy machinery on the base of surface and bulk modification by physical methods", Visnyk Ternopilskogo Nacionalnogo technicnogo univesitetu im. I. Puluya 71 (3), pp. 133 - 145, 2013.

[5] Soroka, O., Rodichev, Yu., Shabeti,a O., Kovalov, V., Vasilchenko, Y. "Control of tool materials structural strength", Reliability of the tool and optimisation of technological systems. Collection of science papers. - Kramatorsk 38, pp. 3 - 11, 2016.

[6] Roebuck, B., Gee, M., Bennett, E., Morrell R. "Measurement Good Practice Guide", No. 20. Mechanical Tests for Hardmetals, Centre for Materials Measurement and Technology National Physical Laboratory Teddington, Middlesex, United Kingdom, TW11 OLW: Crown Copyright, 1999.

[7] Wurster, S., Pippan, R., Jenko, M., Ebner, R., Supancic, P. "Comparison of bending strength of WC-CO hard metal in millimeter and micrometer sized specimens", доступ:http: /www.gruppofrattura.it ocs / index.php / esis / ECF18 / paper / viewFile/6057/1942.

[8] Vereshchaka, A.S., Tret'yakov, I.P. “Cutting tool with wear-resistant coatings”, Moscow: Mashinostroenie, 1986. - 192 p.

[9] Kaplun, P.V., Soroka, E.B., Snozik, A.V. "The Impact of Hydrogen Free Ion Nitriding on Physicomechanical and Performance Characteristics of T5K10 and T15K6", Journal of Superhard Materials 40 (6), pp. 384 - 391, 2018.

[10] Rodichev, Yu., Soroka, O., Kovalov, V., Vasilchenko, Y., Maiboroda, V. "Fracture resistance of the edge of cemented carbide cutting tool", Lecture Notes in Mechanical Engineering: Advanced Manufacturing Processes., pp. 281 - 288, 2020.

[11] Loschak, M. "Prochnost i dolgovechnost tverdych splavov", Kiev: Naukova dumka, 1984. $328 \mathrm{p}$.

[12] Postnikov, S.N. "Perestrojka defektnyh kompleksov v kristallicheskih tverdyh telah pod dejstviem magnitnyh polej doporohovyh energij. Prikladnye problemy prochnosti i plastichnosti. Statika i dinamika deformiruemyh system", Vsesojuznyj mezhvuzovskij sbornik. - Gorkij, 1980. - 138 s.

[13] Malygin, V. "Magnitnoe uprochnenie instrumenta i detalej maschin - Moscow.: Maschinostroenie", 1989. - 112 p.

[14] Bataineha O. "Effect of pulsed magnetic treatment on drill wear", O. Bataineha, B. Klameckia, B. G. Koepkeb, Journal of Materials Processing Technology 134 (2), pp. 190 - 196, 2003.

[15] Kaplun, V.G., Kaplun, P.V. "Ionnoe azotirovanie v bezvodorodnykh sredakh (Ion Nitriding in HydrogenFree Environments)", Khmelnytskyi: KhNU, 2015. - 318 p.

[16] Kaplun, V.G., Pastukh, I.M., Snozik, O.V. "Optimization of Parameters of the Ion Nitriding Mode for Hard Alloy Tooling”, Problemy suchasnogo mashynobuduvannia: Zb. nauk. pr., Khmelnytskyi: TUP, pp. 104 - 106, 1996. 